\title{
Bank Value at Risk (VAR) Disclosures. A Missed Leading Indicator of the 2008 Financial Crisis?
}

\author{
Kiran M. Parthasarathy ${ }^{1}$ \\ ${ }^{1} 370$ F, Melcher Hall, C. T. Bauer College of Business, University of Houston, Main Campus, 4800 Calhoun, \\ Houston, Texas 77004 \\ Correspondence: Kiran M. Parthasarathy, 370 F, Melcher Hall, C. T. Bauer College of Business, University of \\ Houston, Main Campus, 4800 Calhoun, Houston, Texas 77004, USA.
}

Received: June 6, 2020

Accepted: July 9, 2020

Online Published: July 10, 2020

doi:10.5430/afr.v9n3p1

URL: https://doi.org/10.5430/afr.v9n3p1

\begin{abstract}
The financial crisis of 2008 led to devastating consequences such as bankruptcies and recession in the US economy. Many big banks were at the forefront owing to their risk exposures and open positions. Prior research documents that bank financial statements did not provide adequate lead indicators on the looming crisis in reducing information asymmetry. However, there is no prior research focused on the sufficiency of risk disclosures around this time period. This paper seeks to address this gap using Bank Value at Risk (VAR), a single number publicly disclosed in the annual reports of banks. Bank VAR attempts to quantify the worst possible loss the bank expects to have on its trading portfolios under normal market conditions. Using hand-collected data from the annual reports of the top twelve US banks, this study documents that the change in VAR was steady and positive until the point of the crisis and then decreased in the years thereafter. A repeated-measures analysis of variance model is used to study whether two indicators of VAR (year-to-year change in VAR and log-transformed ratio of VAR to the total trading revenue) differ from pre-crisis to the post-crisis levels. Both VAR indicators reveal an increasing trend pre-crisis and are significantly higher pre-crisis compared to post-crisis. This opens the possibility that the trend of VAR might have information content as a potential leading indicator of the crisis. The finding sheds light on efficacy of risk analysis in bank trading portfolios and could have implications for governance.
\end{abstract}

Keywords: VAR, Bank Value at risk, financial crisis, disclosures, bank financial statements, risk analysis of bank trading portfolios

Data: This research has been conducted using publicly available data in bank financial statements

Reporters wanted to understand how Goldman had somehow sidestepped the financial crisis disaster that had befallen everyone else. What they discovered was that in December 2006, Goldman's various indicators, including VaR and other risk models, began suggesting that something was wrong. Not hugely wrong, mind you, but wrong enough to warrant a closer look. In December our mortgage business lost money for 10 days in a row. It wasn't a lot of money, but by the 10th day we thought that we should sit down and talk about it." So Goldman called a meeting of about 15 people, including several risk managers and the senior people on the various trading desks. They examined a thick report that included every trading position the firm held. For the next three hours, they pored over everything. They examined their VaR numbers and their other risk models. They talked about how the mortgage-backed securities market "felt." "Our guys said that it felt like it was going to get worse before it got better," "So we made a decision: let's get closer to home." --- New York Times (2009).

\section{Introduction and Research Question}

This paper revisits the financial crisis of 2008 that had a widespread impact on the economy in terms of bankruptcies, lost jobs, lost capitalization in the stock market, and a deep recession in the US economy that rippled out worldwide (Bezemer, 2010, Reich, 2014 and Hall, 2010). Not considering the monetary impact of factors such as unemployment, defaults in housing and bankruptcies of several firms, the bailing out of banks by Treasury's Troubled Assets Relief Program (TARP) alone costed the country more than $\$ 500$ million (Bayazitova and Shivdasani, 2012).

When an event of this magnitude occurs, there is often a question of whether there were leading indicators for the crisis. For instance, Desai, Rajagopal and Yu (2016) examine whether financial statements of bank holding companies 
contain information of "impending distress". Similarly, studies have examined whether reporting of fair values, asset securitization etc., played a role in foreshadowing the crisis (Barth and Landsman 2010; Badertsher, Burks and Easton 2012). Broadly, these indicators focus on those derived from recognized financial numbers in the bank statements.

However, not all risk is reflected in the numbers in the financial statements. Separately, one of the main factors leading to this debacle was the deep and widespread implications of excessive market risk-taking by banks, mainly the big banks with considerable trading exposures (Reinhart and Rogoff, 2008). At the core of the review was whether the financial statements of these banks and the disclosures within them induced a moral hazard problem (Goh et al, 2015) by disincentivizing proper disclosure of risk. The value of such disclosure has been underscored by Healy and Palepu (2001) who point out that firm's disclosure policies may be related to governance.

One of the key elements of such disclosure is the Bank Value at Risk (VAR) which is a single number publicly disclosed in the annual reports of banks. VAR is a single yet powerful number of market exposure risk, calculated by the banks to signify the worst possible loss on the trading positions, assuming normal market conditions (Jorion, 2002). In regard to the financial crisis of 2008, there has been considerable focus on the elements of financial statements that portended the crisis. However, there is little research on whether the disclosures in the statements, specifically, VAR might be a candidate for inclusion in the portfolio of leading indicators of financial crisis of 2008. This paper seeks to address this gap. Thus, the central research question in this paper is: Do changes in VAR represent a leading indicator of financial crisis.

The consequences of not addressing this research is that we might be overlooking an important piece of the preemptive mechanism viz. the pattern of increase in self-calculated market risk exposures from within the bank. So, if there is more focus on analyzing this number using a time series approach, would we have better warning signs should a crisis brew in the future?

The remainder of this paper is structured as follows. I begin with a discussion of the prior literature (section 2) and define VAR, and develop hypotheses specifying how VAR might be a leading indicator (section 3), and then I present the data, methodology, and results (section 4), and conclude the paper with a discussion of the implications and limitations of the findings (section 5).

\section{VAR and Prior Literature}

\subsection{Value at Risk (VAR)}

In prior decades, when financial risks increased and financial institutions declared bankruptcies (Barings Bank, Asian Crisis, Metalgesallshaft, Orange County, Long Term Capital Management), J.P.Morgan developed a new early warning signal called VAR. This VAR was a single number which showed the maximum loss a bank would stand to lose on its underlying portfolio of trades, under normal adverse market conditions, the definition of which was left to the banks themselves. The VAR number could be ascertained by the bank every day based on their trading portfolio and open positions. The number itself was based on the underlying portfolio risk's volatility, leverage, diversification, market risk, credit risk and a stress test (New York Times, 2009). In the words of Jorion (1996), "VAR summarizes the worst loss over a target horizon with a given level of confidence." To elaborate, VAR measures the maximum amount of loss a trading portfolio can lose under normal market conditions, what is the most a portfolio of a bank can lose over a certain time period (for example, a month) and at what confidence level (For example, 95\%). While this measure mainly captures the market risk in normal market conditions, some banks also disclose the CVAR (credit risk), operational risk and other related risks. The focus of this paper is limited to VAR because disclosures concerning additional risk metrics including CVAR is not mandatory unless foreign currency risk is involved. The VAR is required to be publicly disclosed in the financial statements of the bank. Banks come up with this number based on proprietary models and reports run within their own banks.

\subsection{View on VAR}

Goldman Sachs, in the introductory quote of this paper, cites the VAR indicator to be one of the reasons for withdrawing their trading exposures and averting bankruptcy during the financial crisis of 2008 (New York Times, 2009). While Goldman presents this information, there are others in popular press who have criticized the VAR number as the cause for the crisis (Triana, 2011) and (Taleb, 1997). here are some views that suggest that VAR may not be a useful leading indicator. A recent book (Triana 2011) claims that VAR was flawed because it encouraged the banks to take high risks. Specifically, according to Triana (2011), VAR did not reflect the risks inherent in the trading exposures, which essentially increases rather than decreases risk. This view is echoed in Taleb (1997) who writes that VAR is sensitive to model specification, and as a result, while as a measure VAR may reveal risks, it does 
not reveal the risk of using it. Thus, the criticisms on VAR in popular press after the financial crisis of 2008, suggest that the problems in interpreting this number precipitated the crisis.

\subsection{Financial Crisis of 2008}

In 2007-2008, the United States went through a Financial Crisis of unprecedented proportions, comparable only to the Great Depression of 1933. In the years preceding the crisis, the economy had a situation of monetary excesses as defined by unusually low interest rates (Taylor, 2009). Low interest rates have been prevalent in the past, but this time the low interest rates also led to lending in the housing market. One of the reasons the low interest rates attracted the housing market is because of the overall promotion of home ownership in the United States by the government. Subprime mortgages involved lending to potential homeowners who had low credit risk. However, these housing loans were made at a floating rate (prime) plus a larger than usual credit spread to compensate the bank for the higher credit or counterparty risk. Thus, the subprime mortgage market was replete with loans which banks assumed at a high credit risk and a floating interest rate (with a big interest spread) (Demyanyk and Van Hemert, 2011). The time period when this happened started with the low interest rates of 2002-2004. The floating interest rate slowly began increasing until it peaked around 2007 to 2008. As the floating interest rate increased, the borrowers had to pay interest at a higher interest rate. Simultaneously, as the interest rates climbed upward, the economy also started tightening as businesses could not get loans at cheap interest rates like before. Borrowers of subprime mortgage loans became high counterparty risk and inevitably defaulted on these loans (Laux and Leuz 2010), leading to the huge spiral of defaults in the financial crisis.

Initially, from the top banks' point of view, lending on these subprime mortgages involved receiving a higher bid-offer spread, which meant more profits. But it became pointless when the loans were so risky in the first place that after the first 3 years (Liao et al, 2013), the spiral of defaults led to losses on the principal and the interest. Eventually, it all culminated into a recession. Unemployment soared, and investment Banks suffered huge trading losses and had to either be shut down or supported by the federal government (Reinhart and Rogoff, 2009).

\subsection{General Explanations on What Led to the Financial Crisis of 2008}

Barth and Landsman (2010) examined whether financial reporting contributed to the crisis and discuss how fair values in financial statements were not the reason for the crisis because securitizations, and that derivative information and loan loss provisions had a larger role to play in the crisis. Their paper also discusses how transparency of information with respect to derivatives were insufficient (an example would be credit default swaps).

Crotty (2009) points out that the deep reason for the global financial crisis was the loose financial regulation. Whether it is the large number of unprotected credit default swaps entered into by AIG or the bonuses approved for the Merrill Lynch employees by the board, the overarching theme of unregulated capital markets under the premise of self-correction through open markets, did not work. Second, Crotty (2009) also calls for analysis of Basle I and II rules which had mis-matched incentives. For example, highly rated companies needed to keep less securities. However, in order to get these ratings, companies paid for it themselves. Thus, the rating agencies may have had a conflict of interest. Third, Crotty (2009) also points out that the innovative financial products were extremely complex, thereby leading to potential miscalculation in pricing and misunderstanding of risks involved, including contagion risks. In addition, this paper calls for VAR analyses be centralized rather than self-reported as a way of increasing its usefulness. Finally, when the credit ratings were brought down, Crotty (2009) and others opine that a contagion effect deepened and spread the crisis internationally. These comments lend credence to some potential governance oversights both at the bank level and at the macro-level.

In an analysis of what went wrong during the financial crisis and possible reasons on why it did not get averted earlier, Taylor (2009), identifies the basic issue as monetary excesses which went unchecked. This paper points out that the international conditions in housing markets and credit markets dovetailed those in USA which exacerbated the problem even more. The paper focuses on excessive risk taking in the climate of low interest rates and the punts on poor housing credit. Regarding the amplification and the prolonging of the crisis, the paper attributes it to the complex securitization instruments and poor understanding of it. The paper does not look into the possibility of a lack of governance or emphasis on the internal warning signals emanating from the models.

Leading experts point to the Credit Default Swaps (CDS) market to be a major factor in precipitating the Financial Crisis, so no discussion on the financial crisis of 2008 would be complete without a discussion on CDS. A CDS, is a securitization instrument (also known as an insurance) which secures the buyer of the default swap in the event of a credit default. Thus, it is simply an over-the-counter (OTC) derivative market for these structured default swaps (Stulz, 2010). The pricing is typically based on the credit of the subprime loans. During the financial crisis, several 
credit default swap products were bundled together and traded in secondary markets, thereby making it difficult to understand the total amount notional outstanding default amounts. Many authors including Stulz (2010) argue that credit default swaps did not really help hedge the risks on subprime mortgages during the crisis simply because the underlying markets were not liquid and efficient. For banks selling these credit default swaps, the risk on the subprime mortgage loans was really doubled because they risked a pay out if there is a default on these syndicated loans, which they were part of. Further, having sold a credit default swap, they would have also had to payout on the swap, if the underlying interest rate increased. Thus, this contagion within the bank itself was a contributor to the crisis.

Another factor which contributed to the crisis was that the world's central banks and bank supervisors adopted principles for banks' capital standards, and U.S. banking regulators made adjustments to implement them. Among the most important was the requirement that banks hold more capital against riskier assets. Simultaneously, fatefully, the Basel rules made capital requirements for mortgages and mortgage-backed securities looser than for all other assets related to corporate and consumer loans. Thus, the capital requirements for banks' holdings of Fannie's and Freddie's securities became less than for all other assets except those explicitly backed by the U.S. government.

Desai et al. (2016), look at the financial statements of the banks, and another four factors (excluding VAR), to see if these showed some signs of the impending crisis. The four factors they looked at was the activity among short sellers (did the trading among short sellers suggest an impending crisis), S\&P ratings (did the credit ratings foreshadow the crisis), equity analysts (did the trading pattern of analysts suggest they knew about the crisis), and auditor behavior (did the auditors perceive higher credit risk and therefore charge higher fees to the bank holding companies they audited in the pre-financial crisis period)? These four factors were selected to be proxies of credit risk, interest rate risk, liquidity risk and interest rate risk respectively. They test whether these four factors impact the subsequent bank failures. Desai et al. (2016) use banks loan to asset ratios, construction and home/ non-residential loans to total loans as proxies to capture credit risk and market risk and find this information to be positively correlated with future bank failures. Their findings also suggest that the short-sellers had increased sensitivity to impending bank failures. However, they did not find evidence that credit ratings or audit fees reflected the heightened risk of subsequent bank failures. While these proxies are ideal for the financial crisis of 2008, they do not capture the market trading risk from derivatives and other instruments, which would be captured by tracking the VAR disclosures, as is highlighted in my paper.

\subsection{Differing Positions on VAR in Existing Literature}

In the paper on use and misuse of value-at-risk analysis for bank balance sheet risk analysis, Matz (2004), explains the three different kinds of VARs. First is the historical VAR (based on historic volatility of underlying variables during unlikely events). Second is the analytical or correlation VAR which examines the correlation between two or more assets or financial instruments. Third is the Monte-Carlo simulation VAR which uses sophisticated computer-generated models to simulate different scenarios (including negative). Since this is a relatively newer technique, Monte-Carlo simulations can capture the risks of option sales in the VAR number. This paper goes on to point out that while VAR is a good number to capture the risk inherent in derivatives; it could potentially be problematic to gauge the overall risk in a balance sheet.

However, we do not have any guidelines on how much increase in magnitude of VAR is too much. When should the bank start pulling out its exposures? Current reporting mandates that banks disclose the VAR number; however, there are no recommendations on when the increase in VAR or VAR as a percent of Total Trading Revenues is too risky. Thus. this paper brings to focus this potential lacuna.

The second issue is that of governance. How did the banks' board of directors view the increase in total trading revenues and the increases in VAR? Was the magnitude of increase not concerning? Was it something that happened very suddenly and therefore did not warrant an increase? Why were the circuit breakers in governance not triggered? Although this topic is outside the direct scope of my paper, I conjecture that some more guidelines on interpretations of publicly disclosed risk numbers might be helpful. In sum, it is important for future research to address the question of how much is too much VAR risk?

Jorion (2002) details how VAR can be used to measure the variability of subsequent trading revenues. Using information from the disclosures of a hand collected sample of 8 banks' financial statements, Jorion (2002) finds that VAR based volatility forecasts and disclosures are relevant and have information content to future market risks. He uses only 8 large banks because these are the banks which are actively trading a large notional value of derivatives. These banks have proprietary risk management desks which use valuation methods and software such as Riskmetrics (J.P. Morgan). This lends itself to their calculating VAR appropriately. 


\section{Hypothesis Development}

Jorion (2002) tests for the information content in VAR by looking for the effect of the standard deviation of VAR on unexpected trading revenues. In other words, did the volatility in the VAR numbers explain the level of unexpected trading revenues? Jorion (2002) uses an ordinary least squares model. I do not use this model as too many extreme observations in the 2005-2009 time period may likely skew the results. Instead, I use a simple time trend analysis of the change VAR and VAR as a percentage of Total Trading Revenues to assess the impact of VAR as a leading indicator of the crisis.

As described above, there are two conflicting views on whether VAR can be a candidate for a leading indicator of the financial crisis. If it were a leading indicator, what pattern may we observe? One pattern would be that the VAR rated numbers are elevated prior to the crisis. In contrast, if it has no information value, we should see no difference in the pre- versus post-crisis phases. Two indicators of VAR are change in VAR year over year and VAR that is normalized for size. I use these two operationalizations to specify my hypothesis below:

$\mathrm{H}_{0}$ : The change in the VAR numbers in the years before and up until the crisis is not significantly different from the change in the VAR numbers after the crisis.

$\mathrm{H}_{\mathrm{a}}$ : The change in the VAR numbers in the years before and up until the crisis is significantly different from the change in the VAR numbers after the crisis.

In order to index VAR normalized for size, I use VAR as a percent of Total Trading Revenue of the bank as an indicator of the information content . This leads to the following hypothesis:

$\mathrm{H}_{0}$ : The VAR/TTR before and up to the crisis is not significantly different from the VAR/TTR after the crisis.

Ha: The VAR/TTR before and up to the crisis is significantly different from the VAR/TTR after the crisis.

\section{Data and Methodology}

\subsection{Sample Selection Procedure - Selection of Banks}

The sample selection procedure consists of the top 12 banks of USA as defined by total assets. I choose only the top twelve banks because these typically have VAR data, owing to considerable trading assets and taking it as of 2017 enables me to look at the time trend over a decade (pre and post the crisis). Additionally, the VAR data is typically generated by sophisticated trading software such as Riskmetrics (J.P. Morgan) which only the top banks tend to have. This approach has been taken by Jorion (2002), who takes the quarterly VAR data for a sample of eight banks. He states that he restricts it to eight banks because of availability of publicly disclosed VAR data. Table 1 shows the banks in the sample; twelve big banks in the USA, calculated in the Bankrate website (Note 1). I take only the top twelve banks because these are the banks which have maximum trading volatility from interest rate risk, foreign currency risk, stock price risk and commodity price risk. These banks have considerable resources poured into risk management software to analyze trading positions to calculate and report the VAR. These are also the banks which were at the forefront of the crisis due to their lending on home mortgage loans. The VAR number would indirectly reflect the open positions on the loans via the exposure to floating interest rate risk.

Table 1. Bankrate: America's 12 Biggest Banks as of 2017

\begin{tabular}{ll}
\hline Rank & Bank Name \\
\hline 1 & JPMorgan Chase \& Co. \\
2 & Bank of America Corp. \\
3 & Wells Fargo \& Co. \\
4 & Citigroup Inc. \\
5 & Goldman Sachs Group Inc. \\
6 & Morgan Stanley \\
7 & U.S. Bancorp \\
8 & PNC Financial Services Group \\
9 & TD Group US Holdings LLC \\
10 & Capital One Financial Corp. \\
11 & Bank of New York Mellon Corp. \\
12 & HSBC North American Holdings Inc. \\
\hline
\end{tabular}

\subsection{Variable Definition}

I hand collect relevant bank disclosure data for these top twelve banks from their publicly available annual reports in the www.sec.gov website. I am primarily interested in two key numbers. The first number is the VAR number 
disclosed. This is a voluntary disclosure and is calculated by each bank using their own risk software and methodology. From the VAR, I computed $\triangle V A R$ as the change in VA from one year to the next, for each year for each bank. This allows each firm to serve as their own control.

The second variable of interest is the VARPercent, computed as the VAR divided by the Total Trading Revenues. This is known as Revenues from Trading. The Revenues from trading is a recognized number taken from the main operating results of the bank. By using the Revenues from Trading in the denominator, I have a scaling factor which corrects the normalized VAR numbers by size. The VARPercent tracks the level of total market risk in a firm as a percentage of its Total Trading Revenues. The percentage was log transformed to skewness in the underlying distribution and use the logVARPercent for the main test and the robustness check.

Finally, I create a discrete variable called crisis which takes the value of 1 if the year of the crisis is anywhere between 2005 to 2009 inclusive and 0 otherwise. By starting the crisis window in 2005, I am able to study whether the VAR was a lead indicator of the crisis. I close the crisis window at 2009 because the official close of the crisis per the arbiter of US elections (U.S. National Bureau of Economic Research) is June 2009. I close the window in 2015 to see if the VAR statistics showed a sustained lower trend, post the crisis.

The table below summarizes VAR for Citi-wide trading portfolios at and during 2011 and 2010, including quarterly averages. Historically, Citi included only the hedges associated with the CVA of its derivative transactions in its VAR calculations and disclosures (these hedges were, and continue to be, included within the relevant risk type (e.g., interest rate, foreign exchange, equity, etc.)). However, Citi now includes both the hedges associated with the CVA of its derivatives and the CVA on the derivative counterparty exposure (included in the line "Incremental Impact of Derivative CVA"). The inclusion of the CVA on derivative counterparty exposure reduces Citi's total trading VAR; Citi believes this calculation and presentation reflect a more complete and accurate view of its mark-to-market risk profile as it incorporates both the CVA underlying derivative transactions and related hedges.

\begin{tabular}{|c|c|c|c|c|}
\hline In millions of dollars & $\begin{array}{r}\text { Dec. 31, } \\
2011 \\
\end{array}$ & $\begin{array}{r}2011 \\
\text { Average }\end{array}$ & $\begin{array}{r}\text { Dec. 31, } \\
2010 \\
\end{array}$ & $\begin{array}{r}2010 \\
\text { Average } \\
\end{array}$ \\
\hline Interest rate & $\$ 250$ & $\$ 246$ & $\$ 235$ & $\$ 234$ \\
\hline Foreign exchange & 51 & 61 & 52 & 61 \\
\hline Equity & 36 & 46 & 56 & 59 \\
\hline Commodity & 16 & 22 & 19 & 23 \\
\hline Covariance adjustment ${ }^{(1)}$ & (118) & $(162)$ & $(171)$ & (172) \\
\hline $\begin{array}{l}\text { Total Trading VAR- } \\
\text { all market risk factors, } \\
\text { including general } \\
\text { and specific risk } \\
\text { (excluding derivative CVA) }\end{array}$ & $\$ 235$ & $\$ 213$ & $\$ 191$ & $\$ 205$ \\
\hline $\begin{array}{l}\text { Specific risk-only } \\
\text { Component }{ }^{(2)}\end{array}$ & $\$ 14$ & $\$ 22$ & $\$ 8$ & $\$ 18$ \\
\hline $\begin{array}{l}\text { Total-general } \\
\text { market factors only }\end{array}$ & $\$ 221$ & $\$ 191$ & $\$ 183$ & $\$ 187$ \\
\hline $\begin{array}{l}\text { Incremental Impact of } \\
\text { Derivative CVA }\end{array}$ & $\$(52)$ & $\$(24)$ & $\$ \quad(5)$ & $\mathrm{N} / \mathrm{A}$ \\
\hline $\begin{array}{l}\text { Total Trading and } \\
\text { CVA VAR }\end{array}$ & $\$ 183$ & $\$ 189$ & $\$ 186$ & N/A \\
\hline
\end{tabular}

Figure 1. Example of VAR disclosure by a leading bank

(Excerpt from Citibank Annual Report: 2011)

Figure 1 shows the example of an annual VAR footnote disclosure, using an excerpt from Citibank's annual report. This is a standard format used by most banks, where the various parts of the VAR disclosure is self-reported, as in exposure to interest rate risk, commodity price risk, foreign currency risk and stock price risk. Most banks use back testing and report the information at anywhere in the range of $90 \%$ to $99 \%$ confidence level. The confidence level 
means the level of certainty with which they are able to gauge the worst possible loss on their exposure. All banks in my sample report the Total VAR in the Annual Reports and I use this number.

Table 2. Descriptive Statistics: Mean and Standard Deviation for Change VAR

\begin{tabular}{|c|c|c|c|c|}
\hline Crisis & $\mathrm{N}$ & Year & Mean & $\begin{array}{l}\text { Standard } \\
\text { Deviation }\end{array}$ \\
\hline 1 & 9 & 2006 & 3222222.22 & 16968262.86 \\
\hline 1 & 9 & 2007 & 8177777.78 & 13700800.87 \\
\hline 1 & 9 & 2008 & 34222222.22 & 30180572.30 \\
\hline 1 & 10 & 2009 & 19950000.00 & 34156250.44 \\
\hline 0 & 10 & 2010 & -36850000.00 & 51938344.86 \\
\hline 0 & 10 & 2011 & -9060000.00 & 12738846.97 \\
\hline 0 & 11 & 2012 & -20881818.18 & 42067251.35 \\
\hline 0 & 11 & 2013 & -8554545.45 & 14147463.63 \\
\hline 0 & 11 & 2014 & -3727272.73 & 4204067.29 \\
\hline 0 & 10 & 2015 & -1520000.00 & 7108179.95 \\
\hline
\end{tabular}

Table 2 shows the descriptive statistics relating to the study. Mean $\triangle V A R$ and the standard deviation from the years 2005 to 2015. The first year included is 2006 because the difference (ChangeVAR) is calculated as difference between VAR in 2005 and VAR in 2006. The mean change in VAR represents the signed mean change in VAR for the top twelve banks. It is very interesting to note that the mean change in VAR was 2.5 times higher in 2006 compared to 2005. Thus, there was an early warning signal in the mean Change VAR number. The Change VAR was the highest in 2008 (at the peak of the financial crisis) but the volatility in change VAR (the standard deviation) is highest in 2009. The year 2009 was when the crisis officially ended. As the banks were unwinding their exposures, the standard deviation in the change VAR among the twelve banks reached a high of US\$ 34 million. In 2010, although the mean change in VAR reduced from the previous year, the standard deviation of change VAR reached an all time high of US\$51,938,000. I attribute this to the differential effect the crisis had on different banks and the timing of the unwinding of the exposures for each individual bank, leading to higher standard deviation in the number. The mean increase in VAR from one year to another pre and until the crisis is a positive number $(\$ 13,302,500)$ whereas the mean change in VAR after the crisis is a negative $\$ 12,72,3030$. Notice that these are not absolute VAR numbers but is the change from year to year. This clearly shows that the change VAR number consistently climbed up from year to year.

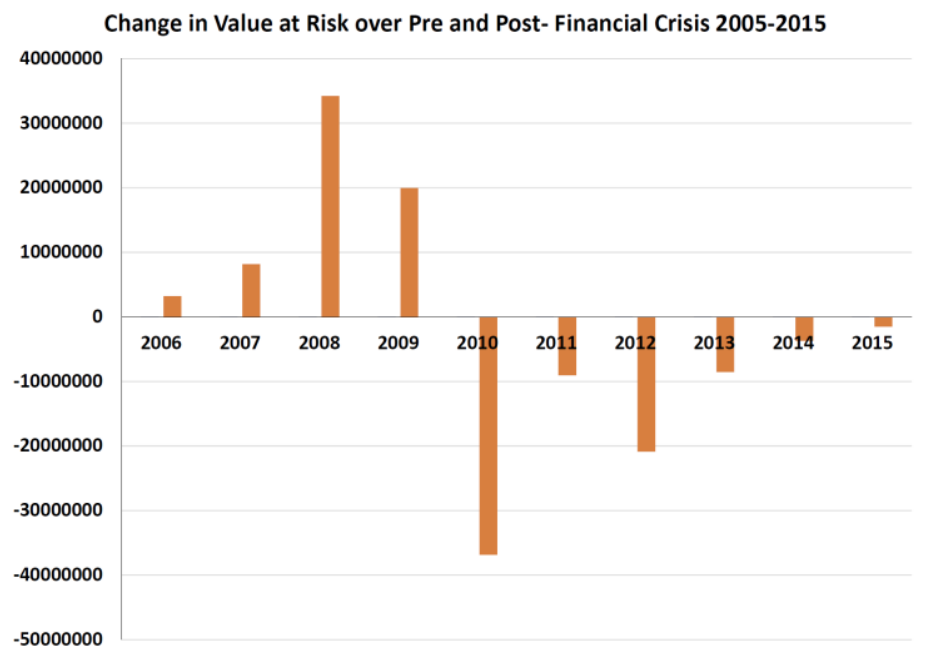

Figure 2. Change in VAR over Pre and Post - Financial Crisis 2005-2015

Figure 2 diagrammatically represents the $\triangle V A R$ number in a bar graph. There is an increase in the $\triangle V A R$ from 2006 to 2007 , even before the numbers peaked in 2008 (the year of the financial crisis). There is a steady decline after 2009. 
Table 3. Descriptive Statistics: Mean and Standard Deviation for VAR Percent

\begin{tabular}{|c|c|c|c|c|}
\hline Crisis & $\mathrm{N}$ & Year & Mean & $\begin{array}{l}\text { Standard } \\
\text { Deviation }\end{array}$ \\
\hline 1 & 8 & 2005 & 2.35 & 3.70 \\
\hline 1 & 8 & 2006 & 1.07 & 1.37 \\
\hline 1 & 9 & 2007 & 4.02 & 6.29 \\
\hline 1 & 9 & 2008 & 6.94 & 21.50 \\
\hline 1 & 9 & 2009 & 2.90 & 3.72 \\
\hline 0 & 8 & 2010 & 1.94 & 1.76 \\
\hline 0 & 8 & 2011 & 1.73 & 1.47 \\
\hline 0 & 8 & 2012 & 1.48 & 0.69 \\
\hline 0 & 8 & 2013 & 1.15 & 0.63 \\
\hline 0 & 8 & 2014 & 1.78 & 2.40 \\
\hline 0 & 7 & 2015 & 1.89 & 2.78 \\
\hline
\end{tabular}

Table 3 shows the VAR percent (VAR / Total Trading Revenues) for the time period of 2005 to 2015 . The VAR percent in noticeably higher in 2007 than in 2006 (2.75 times higher). The standard deviation is 3.59 times higher in 2007 compared to 2006 and 1.7 times higher than in 2005. Thus, the lead indication happened in the transition from the year 2006 to 2007 and not earlier (from 2005 to 2006, there is a decline in the mean and standard deviation. Thus the lead indication happened only 2 years before).

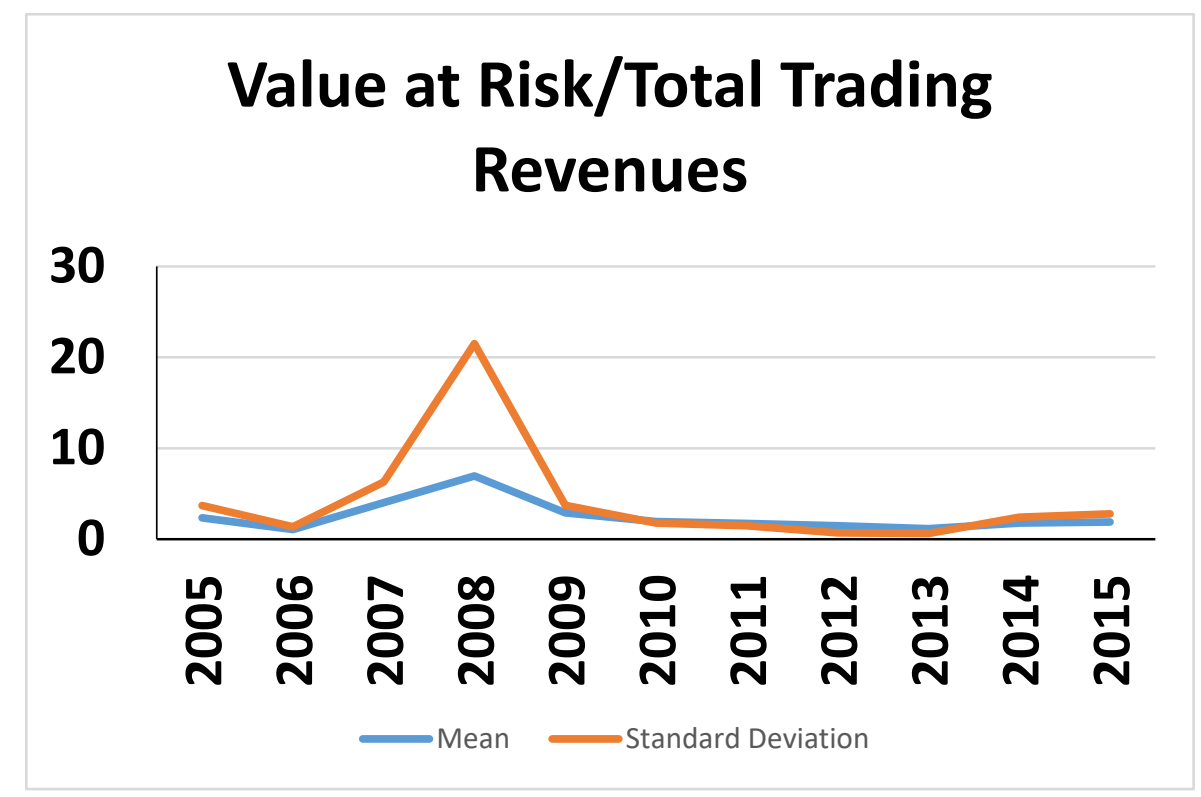

Figure 3. Change in LogVARPercent through the Financial Crisis

Figure 3 shows a slight dip from 2005 to 2006, then an increase in both the standard deviation and the mean VAR Percent from 2006 to 2007 and then a sharp increase from 2007 to 2008 . We then see significantly lower numbers from 2009 to 2015. This graph indicates that the lead indication did come from 2006 onwards. As Goldman Sachs executives point out, the reports did not indicate a huge increase (lead indicator) but did indicate enough of an increase to warrant withdrawing from the market at that time. Another important factor to consider would be the VAR disclosed in quarterly reports from 2007 to 2008. As this analysis is based on annual reports, I leave it to future research to do the analysis on this question.

\section{Main Results}

To test the $\mathrm{H} 1$ and $\mathrm{H} 2$, I specified two separate repeated-measures ANOVA with time (pre- versus post-crisis) as the repeated-measures predictor of $\triangle \mathrm{VAR}(\mathrm{H} 1)$ and $\log$ VARPercent $(\mathrm{H} 2)$. 
In regard to $\mathrm{H} 1$, the analysis indicated a significant effect of the repeated-measures factor; the $\triangle \mathrm{VAR}$ in the pre and at-crisis time period is significantly higher compared to the $\triangle \mathrm{VAR}$ in the post crisis period $(\mathrm{F}=10.57$ and $\mathrm{p}<0.01)$. Thus, $\mathrm{H}_{1}$ is rejected, and $\mathrm{H} 1_{\mathrm{a}}$ is supported.

In regard to $\mathrm{H} 2$, the analysis indicated a significant effect of the repeated-measures factor; the $\log \mathrm{VARPercent}$ in the pre and at-crisis time period is significantly higher compared to the VAR percent in the post crisis period ( $\mathrm{F}=8.52$ and $\mathrm{p}<0.05)$. Thus, $\mathrm{H} 2_{0}$ is rejected, and $\mathrm{H} 2_{\mathrm{a}}$ is supported.

Taken together, the main tests show that the pre-crisis years leading upto the crisis in 2008/2009 had a higher mean in $\triangle \mathrm{VAR}$ and VARPercent compared to the post-crisis years.

\section{Robustness checks}

The previous analyses assume that both $\triangle \mathrm{VAR}$ and $\log \mathrm{VARpercent}$ are distributed normally. I therefore tested the hypotheses relating to $\triangle \mathrm{VAR}$ and $\log \mathrm{VARpercent}$ using the non-parametric Wilcoxon rank-sum exact test of difference between the means pre- versus post-crisis.

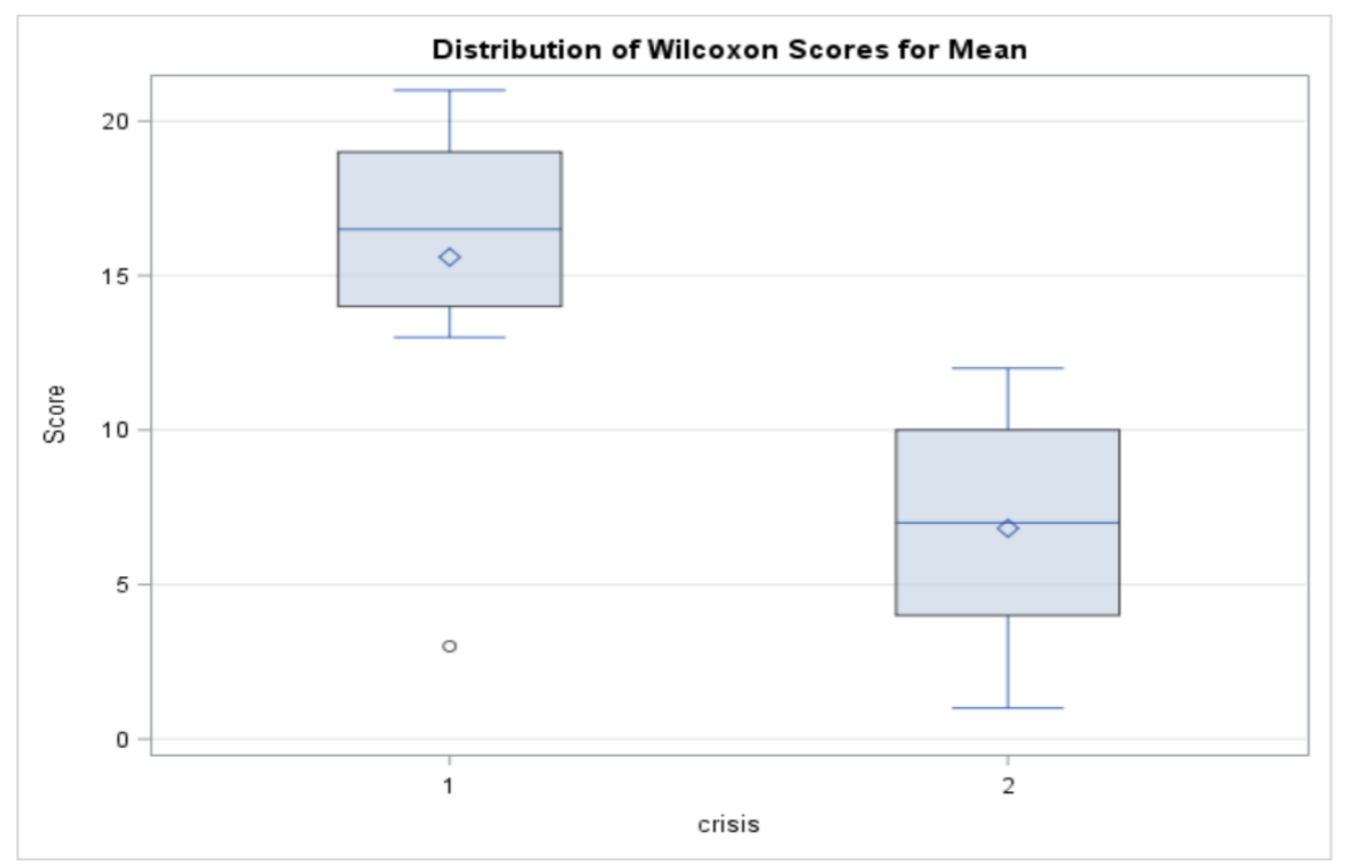

Figure 4. Wilcoxon Test for Change $\triangle \mathrm{VAR}$ in through the Financial Crisis

In regard to $\triangle \mathrm{VAR}$, the non-parametric test reveals that $\triangle \mathrm{VAR}$ is higher in the pre-crisis phase (15.6) compared to the post-crisis phase (6.82), Kruskal-Wallis Exact test, $\chi^{2}(1 \mathrm{df})=10.49, \mathrm{p}=0.0012$ (Figure 4). Thus, $\mathrm{H} 1_{0}$ is rejected, and $\mathrm{H} 1_{\mathrm{a}}$ is supported.

The $\log$ VARpercent is not statistically significantly different, though directionally higher in the pre-crisis phase (10.67) compared to the post-crisis phase (7.13), Kruskal-Wallis Exact test, $\chi^{2}(1 \mathrm{df})=2.08, \mathrm{p}=0.15$ (Figure 5). Thus, $\mathrm{H} 1_{0}$ is not rejected. 


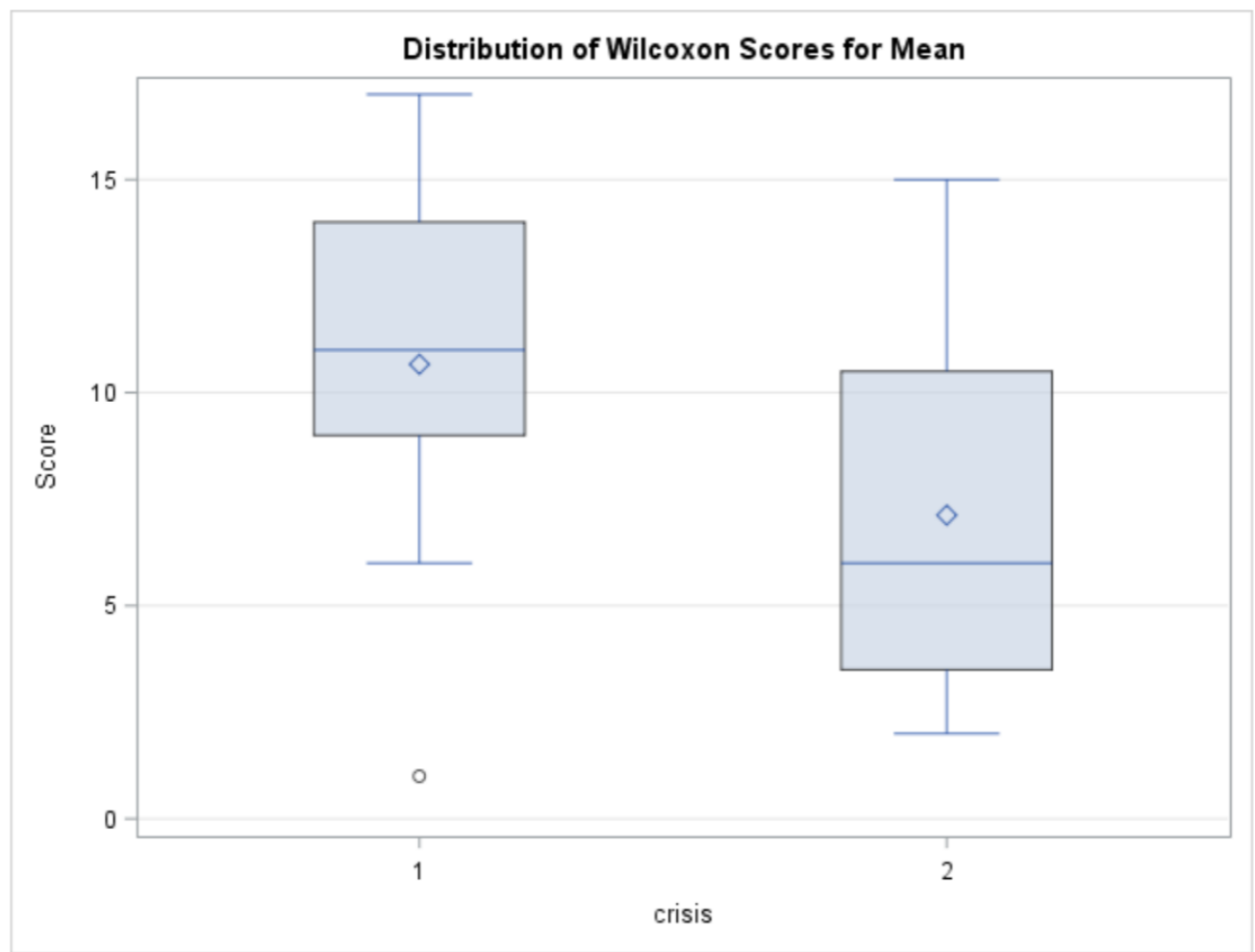

Figure 5. Wilcoxon Test for Change in LogVARpercent through the Financial Crisis

\section{Discussion and Conclusion}

Recognition and disclosure of information in financial statements attempt to reduce information asymmetry for stakeholders. This paper finds preliminary information that lead indication of the financial crisis of 2008 was present in the bank VAR number about 2 years before the crisis. Contrary to discussions in popular literature, the bank VAR disclosure number did increase in the time period before the Financial Crisis of 2008, peaked in the year of the Crisis and fell in the ensuing years. The change in VAR showed a steady positive increase which was evident by 2007. The volatility of the number was also high in the years preceding the crisis. This suggests that the VAR disclosure number has information content, at least in the form of an increasing trend line. If this is contrasted to the trend in the years after the crisis, until 2015, the change in VAR is significantly smaller and has an overall decreasing slope. Thus, this study advances the framework of findings in the field of VAR and bank risk disclosure.

There were many other reasons attributed to the financial crisis, such as credit default swaps, the panic among the banks to unwind the positions leading to the exacerbation of the crisis, the defaults in the home mortgage loan markets and fair value accounting. Because this paper does not take all of these factors and operationalize them into the study design, it is possible that the increase in VAR was documented because of the underlying volatility in these markets and not in the VAR market risk itself. This is a limitation of this study. I leave it to future research to come up with frameworks for addressing it. Separately, it is important to note that the findings are only suggestive of VAR as a potential leading indicator. That the indicator should be different in the pre- versus post-crisis phase is at best a necessary, not a sufficient condition. Additional research with different methodologies and additional covariates are needed to continue to assess the viability of VAR as a leading indicator.

In conclusion, I show in this paper that the increase in VAR was not limited to Goldman Sachs but also the other banks in the top-twelve cluster. Whether this increase was not noted due to problems with corporate governance is not addressed in this paper and I leave it as an avenue for future research. Further, future research can be directed to addressing the information content of VAR in the post-financial crisis world and the efficacy of tightening due to the Frank-Dodd Act and the Volcker reforms. 


\section{Acknowledgements}

I would like to thank Dr. Partha Krishnamurthy for many helpful insights on this topic and the statistical analysis. I would also like to thank Mehreen Baig and Lida Liang for help in data collection and literature synthesis. Lida Liang, additionally, has been very helpful in careful proof reading, formatting and bibliography. Finally, I would like to thank the participants of American Accounting Association's (AAA) Annual Conference at San Diego, 2017 and Washington DC, 2018.

\section{References}

Aebi, V., Sabato, G., \& Schmid, M. (2012). Risk management, corporate governance, and bank performance in the financial crisis. Journal of Banking \& Finance, 36(12), 3213-3226. https://doi.org/10.1016/j.jbankfin.2011.10.020

Barth, M. E., \& Landsman, W. R. (2010). How did financial reporting contribute to the financial crisis? European accounting review, 19(3), 399-423. https://doi.org/10.1080/09638180.2010.498619

Bayazitova, D., \& Shivdasani, A. (2012). Assessing tarp. The Review of Financial Studies, 25(2), 377-407. https://doi.org/10.1093/rfs/hhr121

Bezemer, D. J. (2010). Understanding financial crisis through accounting models. Accounting, Organizations and Society, 35(7), 676-688. https://doi.org/10.1016/j.aos.2010.07.002

Crotty, J. (2009). Structural causes of the global financial crisis: a critical assessment of the 'new financial architecture'. Cambridge journal of economics, 33(4), 563-580. https://doi.org/10.1093/cje/bep023

Demyanyk, Y., \& Van Hemert, O. (2011). Understanding the subprime mortgage crisis. The review of financial studies, 24(6), 1848-1880. https://doi.org/10.1093/rfs/hhp033

Desai, H., Rajgopal, S., \& Yu, J. J. (2016). Were information intermediaries sensitive to the financial statement-based leading indicators of bank distress prior to the financial crisis? Contemporary Accounting Research, 33(2), 576-606. https://doi.org/10.1111/1911-3846.12161

Goh, B. W., Li, D., Ng, J., \& Yong, K. O. (2015). Market pricing of banks' fair value assets reported under SFAS 157 since the 2008 financial crisis. Journal of Accounting and Public Policy, 34(2), 129-145. https://doi.org/10.1016/j.jaccpubpol.2014.12.002

Hall, R. E. (2010). Why does the economy fall to pieces after a financial crisis?. Journal of Economic perspectives, 24(4), 3-20. https://doi.org/10.1257/jep.24.4.3

Ivashina, V., \& Scharfstein, D. (2010). Bank lending during the financial crisis of 2008. Journal of Financial economics, 97(3), 319-338. https://doi.org/10.1016/j.jfineco.2009.12.001

Jorion, P. (2002). How informative are value-at-risk disclosures?. The Accounting Review, 77(4), 911-931. https://doi.org/10.2308/accr.2002.77.4.911

Laux, C., \& Leuz, C. (2010). Did fair-value accounting contribute to the financial crisis?. Journal of economic perspectives, 24(1), 93-118. https://doi.org/10.1257/jep.24.1.93

Liao, L., Kang, H., Morris, R. D., \& Tang, Q. (2013). Information asymmetry of fair value accounting during the financial crisis. Journal of Contemporary Accounting \& Economics, 9(2), 221-236. https://doi.org/10.1016/j.jcae.2013.10.001

Matz, L. (2004). Use and misuse of value-at-risk analysis for bank balance sheet risk analysis. Bank Accounting \& Finance, 18(1), 13-19.

Gabriel Chodorow-Reich, The Employment Effects of Credit Market Disruptions: Firm-level Evidence from the 2008-9 Financial Crisis , The Quarterly Journal of Economics, 129(1), February 2014, 1-59. https://doi.org/10.1093/qje/qjt031

Reinhart, C. M., \& Rogoff, K. S. (2008). Is the 2007 US sub-prime financial crisis so different? An international historical comparison. American Economic Review, 98(2), 339-44. https://doi.org/10.1257/aer.98.2.339

Reinhart, C. M., \& Rogoff, K. S. (2009). The aftermath of financial crises. American Economic Review, 99(2), 466-72. https://doi.org/10.1257/aer.99.2.466

Stulz, R. M. (2010). Credit default swaps and the credit crisis. Journal of Economic Perspectives, 24(1), 73-92. https://doi.org/10.1257/jep.24.1.73 
Taleb, N. (1997). Against value-at-risk: Nassim Taleb replies to Philippe Jorion. Derivatives Strategy, (2).

Taylor, J. B. (2009). The financial crisis and the policy responses: An empirical analysis of what went wrong (No. w14631). National Bureau of Economic Research. https://doi.org/10.3386/w14631

Triana, P. (2011). The number that Killed us: a story of modern banking, flawed mathematics, and a big financial crisis. John Wiley \& Sons. https://doi.org/10.1002/9781119198826

Wilcoxon, F. (1992). Individual comparisons by ranking methods. In Breakthroughs in statistics, 196-202. Springer, New York, NY. https://doi.org/10.1007/978-1-4612-4380-9_16

New York Times. (2009, January 2). Risk Mismanagement. Retrieved from https://www.nytimes.com/2009/01/04/magazine/04risk-t.html

Taleb, N. (1997). Against Value-at-Risk: Nassim Taleb Replies to Philippe Jorion. Retrieved from https://www.fooledbyrandomness.com/jorion.html

\section{Note}

Note 1. (https://www.bankrate.com/banking/biggest-banks-in-america/). Please note that the Bank Rate website ranks the top banks according to their assets and updates it regularly. This is a convenient method for using a secondary source which is based on verifiable and accurate public records. 